\title{
Studies on transmission of white spot syndrome associated baculovirus (WSBV) in Penaeus monodon and $P$. japonicus via waterborne contact and oral ingestion
}

\author{
H.Y. Chou ${ }^{\mathrm{a}, *}$, C.Y. Huang ${ }^{\mathrm{a}}$, C.F. Lo ${ }^{\mathrm{b}}$, G.H. Kou ${ }^{\mathrm{b}}$ \\ a Department of Aquaculture, National Taiwan Ocean University, Keelung 202, Taiwan \\ ${ }^{\mathrm{b}}$ Department of Zoology, National Taiwan University, Taipei 106, Taiwan
}

\begin{abstract}
WSBV (white spot syndrome associated baculovirus) is considered to be the main causative agent of a recently reported disease which has resulted in serious mortality among cultured penaeid shrimp in Taiwan and is characterized by obvious white spots on the body. Shrimp infectivity tests of WSBV were carried out by means of waterborne contact and oral ingestion. Healthy juvenile $P$. monodon and $P$. japonicus and healthy $P$. penicillatus postlarvae were immersed in filtrates prepared from either diseased P. japonicus or diseased P. monodon, both of which exhibited marked white spot signs. Cumulative mortalities of the three tested shrimp species reached $100 \%$ within 4-6 days. Using PCR with a specific primer set, WSBV was first detected in the previously healthy $P$. monodon immersed in filtrate from diseased $P$. monodon $6 \mathrm{~h}$ postinoculation (h p.i.). At 24 h p.i. detection rates reached $90 \%$, and even though the tested shrimp failed to show visible evidence of disease, they nonetheless suffered $33 \%$ mortality. The appearance of WSBV in experimentally infected $P$. penicillatus postlarvae was detected at $24 \mathrm{~h}$ p.i. and reached $100 \%$ by $72 \mathrm{~h}$ p.i. Healthy $P$. monodon fed with diseased $P$. japonicus as well as those fed with diseased P. monodon became $80-90 \%$ WSBV-positive 24 h p.i. by PCR and all of the tested shrimp died within $5 \mathrm{~d}$. Obvious white spots appeared on the exoskeleton of shrimp whether they were infected by waterborne contact or orally. WSBV was found highly pathogenic to the three tested shrimp species and was readily transmitted across different penaeid shrimp. (C) 1998 Elsevier Science B.V. All rights reserved.
\end{abstract}

Keywords: WSBV; Transmission; Penaeid shrimp; White spots; PCR

\footnotetext{
* Corresponding author. Tel.: +886-2-2462-2192 ext. 5214; fax: +886-2-2463-4176; e-mail: hychou@ntou66.ntou.edu.tw.
} 


\section{Introduction}

Recently, cultured shrimp in Asia have been menaced with a variety of new infectious viral diseases. From Japan, reports have come of a new acute viral disease which since 1993 has caused more than $80 \%$ mortality among farmed kuruma shrimp (Penaeus japonicus). The causative virus was tentatively designated as rod-shaped nuclear virus of $P$. japonicus (RV-PJ) and redesignated as Penaeid rod-shaped DNA virus (PRDV) in 1996 (Inouye et al., 1994; Momoyama et al., 1994; Nakano et al., 1994; Takahashi et al., 1994; Inouye et al., 1996). In Thailand, systemic ectodermal and mesodermal baculovirus (SEMBV) has been implicated in disease outbreak in black tiger prawn P. monodon (Wongteerasupaya et al., 1995). An explosive epidemic disease (EEDS) of prawn occurred in China in 1993-1994. The virus HHNBV (hypodermal and hematopoietic necrosis baculovirus) was considered to be the causative pathogen of EEDS (Cai et al., 1995).

Similarly, outbreaks of an acute, highly contagious disease of penaeid shrimp which has often caused high mortality and significant economic loss in shrimp hatcheries have occurred throughout Taiwan since 1992. The disease is characterized by obvious white spots on the carapace, appendages and the inside surface of the body, and cumulative mortality reaches $100 \%$ within 2-7 days. A bacilliform viral agent, tentatively designated as WSBV (white spot syndrome associated baculovirus) was found to be the main causative agent of the disease in Taiwan (Chou et al., 1995; Wang et al., 1995; Lo et al., 1996).

While these newly reported penaeid shrimp viruses have brought the cultured shrimp industry in Asia to a critical condition, the results of field surveys suggest that the outbreaks in Japan and China were caused by imported shrimp (Nakano et al., 1994; Cai et al., 1995). Limiting distribution is axiomatic to preventing the spread of viral disease and can help in reducing the prevalence of disease, but the exact parameters of effective and cost-effective distribution control are not clear. In the present study then, for a better understanding of WSBV transmission, we cross-inoculated WSBV from either diseased P. monodon or diseased P. japonicus among penaeid shrimp ( $P$. monodon, P. japonicus and $P$. penicillatus) via waterborne contact or oral ingestion. We believe that such an investigation of WSBV transmission will potentially be of value in further study of the control of WSBV.

Another problem in the control of WSS is that as the virus can be shed from infected stocks that show no clinical symptoms (carrier state), hatcheries sharing the same water may be put at risk even before there is any evidence of the presence of infection. Thus, inasmuch as prevention and quarantine are essential parts of any strategy intended to combat the disease, a rapid diagnosis is urgently needed. The polymerase chain reaction (PCR) with specific primer sets has become a powerful diagnostic tool for identifying specific pathogens (Erlich et al., 1988, Oste, 1988). For a quick diagnosis of WSBV, a specific primer set for PCR was developed using a strain of WSBV from P. monodon (Lo et al., 1996). With this specific primer set and PCR, this paper reports on attempts made to detect WSBV at different $h$ p.i. (hours postinoculation) before the white-spot syndrome first appears on the shrimp. Both waterborne and oral infection pathways were investigated. 


\section{Materials and methods}

\subsection{Shrimp}

The healthy juvenile and young adult shrimp used in this study were verified to be WSBV-free by PCR (Lo et al., 1996) before being subjected to the challenge tests. Diseased shrimp were collected from a culture farm at Wu-Chieh in I-Lan Prefecture in northern Taiwan. All of the shrimp were maintained in aquaria at $25-28^{\circ} \mathrm{C}$ with aeration and fed on artificial, commercially obtained shrimp food twice daily.

\subsection{Shrimp infectivity test via waterborne inoculation}

One infection trial was performed using the filtrate of the epidermis from live or frozen naturally infected $P$. monodon and a parallel infection trial used an identically prepared filtrate from infected $P$. japonicus. In either case, the epidermis from infected shrimp was removed and homogenized in brackish water at $4^{\circ} \mathrm{C}$ at a ratio of 1:9. After being centrifuged at $8510 \times g$ (Sigma $2 \mathrm{~K} 15$ rotor 12141) for $5 \mathrm{~min}$, the supernatant fluid was filtered through a $0.45-\mu \mathrm{m}$ membrane and diluted 500-750 times in brackish water in order to be used as a waterborne inoculum (Chou et al., 1995). For mortality observation, two replicates of 35 juvenile $P$. monodon and $P$. japonicus, and $P$. penicillatus postlarvae (mean weight $0.02 \mathrm{~g}, 0.08 \mathrm{~g}$ and $0.003 \mathrm{~g}$ respectively) were immersed in one of these diluted filtrates for $2 \mathrm{~h}$. Other replicates were similarly exposed to brackish water and served as controls. After inoculation, shrimp were kept in glass aquaria with aeration. Water temperature and salinity were $25-28^{\circ} \mathrm{C}$ and $25-30$ ppt, respectively, throughout the experiment, and mortality was observed daily.

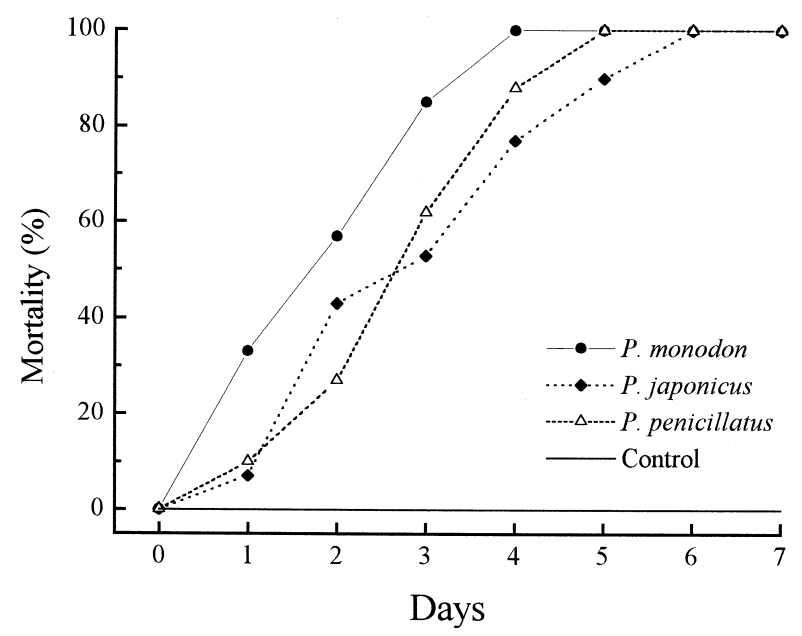

Fig. 1. Cumulative mortalities $(\%)$ of $P$. monodon (0.02 g average weight), P. japonicus ( $0.08 \mathrm{~g}$ average weight) and $P$. penicillatus ( $0.003 \mathrm{~g}$ average weight) experimentally infected by immersion in filtrates from diseased P. monodon. Data shown are the mean of two replicates. 


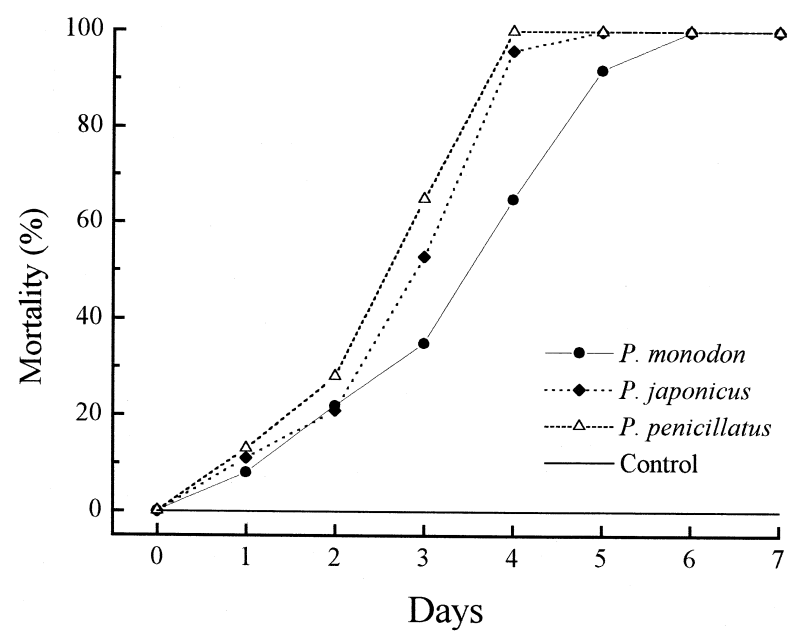

Fig. 2. Cumulative mortalities (\%) of P. monodon (0.02 g average weight), P. japonicus ( $0.08 \mathrm{~g}$ average weight) and $P$. penicillatus ( $0.003 \mathrm{~g}$ average weight) experimentally infected by immersion in filtrates from diseased P. japonicus. Data shown are the mean of two replicates.

For the sampling study, four tanks each containing 35 inoculated juvenile $P$. monodon or P. penicillatus postlarvae were prepared following the procedures described above. From the sampling tanks, $10 P$. monodon were removed at 3, 6, 12, 24 and $48 \mathrm{~h}$ p.i. and groups of 7-10 P. penicillatus were removed at 24,48 and $72 \mathrm{~h}$ p.i. and processed for PCR analysis. Whenever the inoculated shrimp were sampled, a specimen from the control group of healthy shrimp was also taken, the PCR testing of this healthy

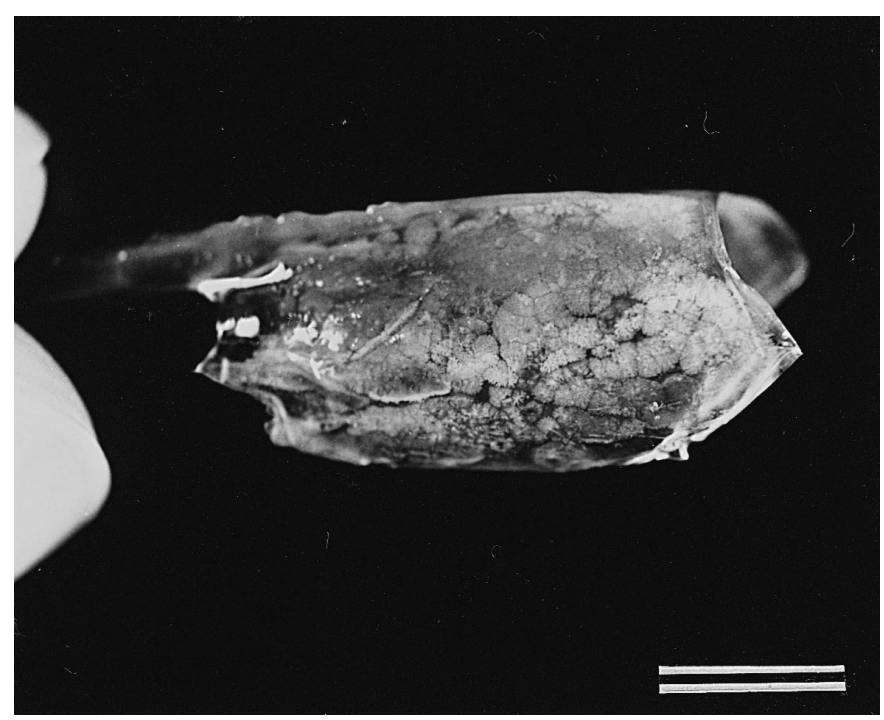

Fig. 3. Carapace removed from $P$. monodon experimentally infected by oral ingestion. Scale bar $=1 \mathrm{~cm}$. 
specimen serving as a negative control. Similarly, at these same times, the respective inocula themselves were also subjected to PCR to serve as a positive control.

\subsection{Shrimp infectivity test via oral ingestion}

Healthy young adult $P$. monodon (mean weight $1.5 \mathrm{~g}$ ) were reared individually in compartments of glass aquaria. After the artificial shrimp food had been withheld for 24 $\mathrm{h}$, the shrimp were started on a once daily diet $(0.2 \mathrm{~g} / 1 \mathrm{~g}$ shrimp body weight $)$ of muscle that contained WSBV excised either from diseased $P$. monodon or from diseased $P$. japonicus. Water temperature and salinity were $25-28^{\circ} \mathrm{C}$ and $25-30 \mathrm{ppt}$, respectively, throughout the experiment. The mortality was observed daily. Sampling and control conditions were analogous to those described above, with groups of 10 shrimp being removed 24 and $48 \mathrm{~h}$ p.i. and processed for PCR analysis.

\subsection{Detection of WSBV in experimental shrimps by PCR}

The primer sets, PCR amplification conditions and protocol used in the present study were those developed by Lo et al. (1996). The presence of WSBV was detected by PCR

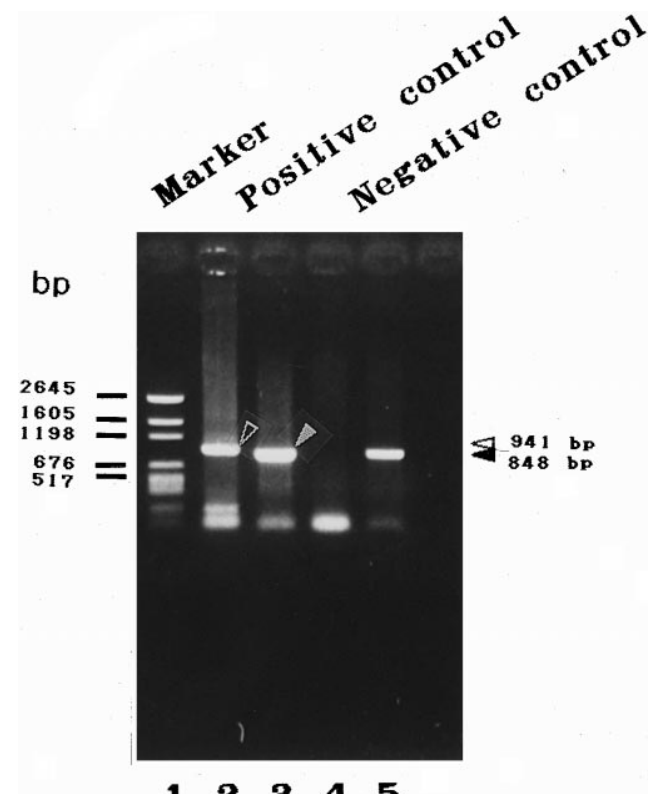

$\begin{array}{lllll}1 & 2 & 3 & 4 & 5\end{array}$

Fig. 4. PCR amplification of WSBV- and shrimp DNA-specific fragments using specific primer sets and DNA extracts from diseased and healthy P. monodon as PCR DNA templates. The WSBV-specific primer set 146 F2 and 146 R2 were used for reactions in lanes 2 and 4. The PCR product is a 941-bp fragment $(\triangleleft)$. The shrimp DNA-specific primers $143 \mathrm{~F}$ and $145 \mathrm{R}$ were used for reactions in lanes 3 and 5 . They prime the amplification of a 848-bp fragment (4). The amplification products were analyzed on a $1 \%$ agarose gel. Lane 1: pGEN DNA size marker. Size of DNA marker indicated in base pairs (bp). Lane 2-3: DNA extracted from diseased P. monodon which was used as positive control in each subsequent PCR reactions. Lane 4-5: DNA extracted from healthy shrimp used as negative control in all subsequent PCRs. 
using the highly specific primer set 146 F2 and 146 R2 developed from a WSBV strain from $P$. monodon. With this primer set, a 941-bp fragment was expected to be amplified from diseased shrimp. Two other primers, $143 \mathrm{~F}$ and $145 \mathrm{R}$, were designed based on published sequences and these were used to prime the amplification of a 848-bp fragment of shrimp DNA. The DNA templates prepared from tested shrimp were extracted from a working leg of the juvenile shrimps or from the abdomen part of shrimp postlarvae from which the cephalothorax had been removed, following the method described by Lo et al. (1996). After excision, the tissue was weighted and then rapidly frozen in liquid nitrogen before being crushed to a fine powder. The processed tissue was placed in a centrifuge tube and an appropriate amount $(1.2 \mathrm{ml} / 100 \mathrm{mg}$ tissue
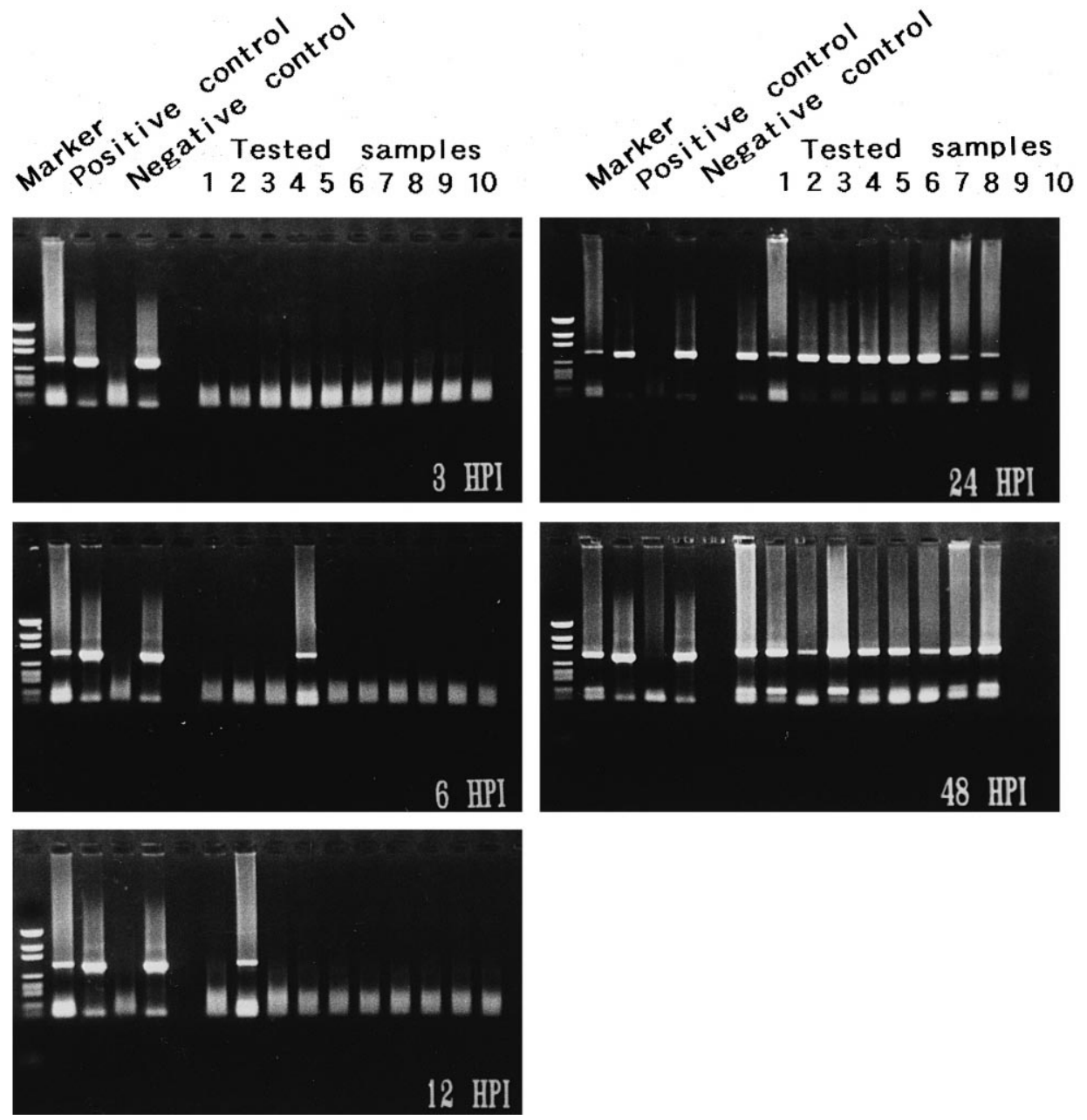

Fig. 5. Detection of WSBV by PCR with WSBV-specific primer sets 146 F2 and 146 R2 using DNA extracts from juvenile $P$. monodon immersed in filtrates from diseased $P$. monodon at different p.i. Positive and negative control lanes as described in Fig. 4. The PCR products were analyzed on a $1 \%$ agarose gel. Marker: pGEN DNA size marker. 
weight) of digestion buffer (100 mM NaCl, $10 \mathrm{mM}$ Tris-HCl, pH 8.0, $50 \mathrm{mM}$ EDTA, $\mathrm{pH} 8.0,0.5 \%$ sodium dodecyl sulfate, $0.1 \mathrm{mg} / \mathrm{ml}$ proteinase $\mathrm{K}$ ) was added. After incubation at $65^{\circ} \mathrm{C}$ for $3 \mathrm{~h}$, the digest was deproteinized by successive phenol/chloroform/isoamyl alcohol extraction, recovered by ethanol precipitation, and dried. The dried DNA pellet was resuspended in a suitable amount of $0.1 \times \mathrm{TE}$ buffer at $65^{\circ} \mathrm{C}$ for $20 \mathrm{~min}$, and stored at $4^{\circ} \mathrm{C}$. For the PCR, $3 \mu \mathrm{l}$ of the resuspended DNA were used.
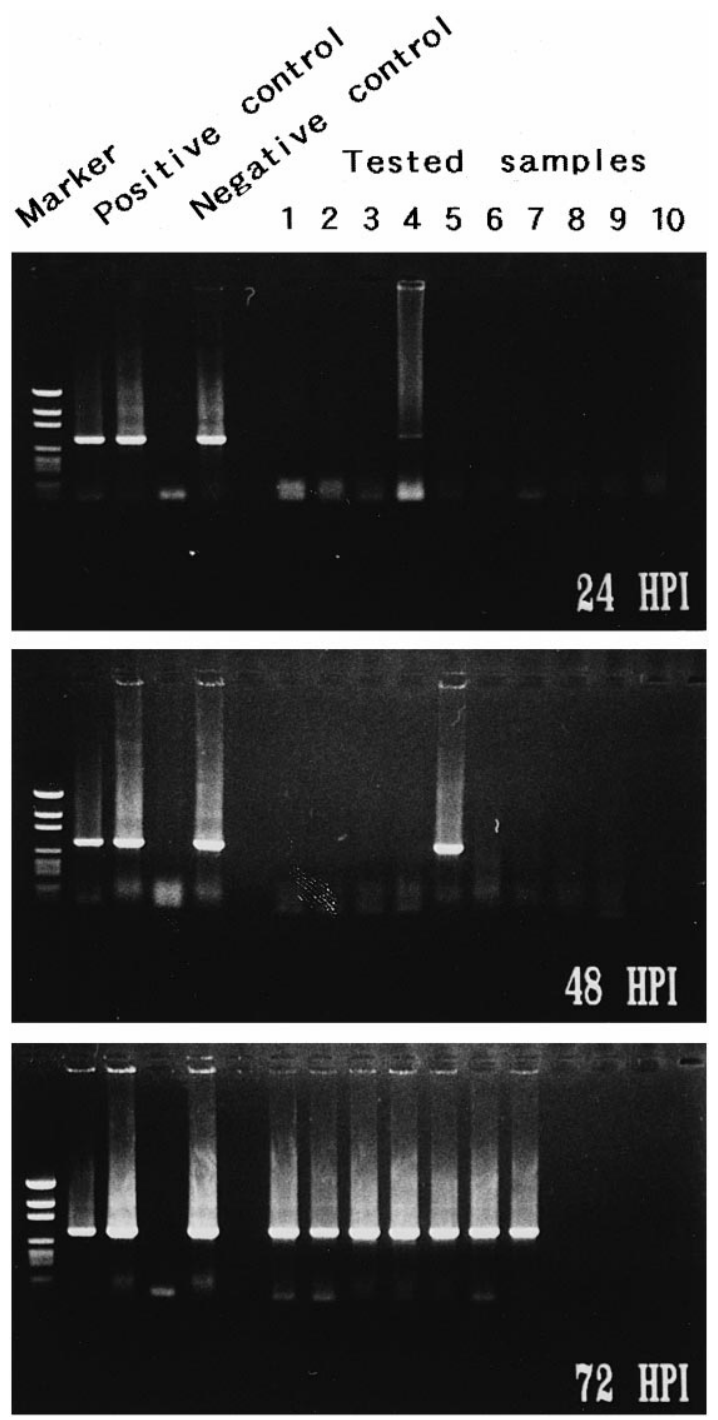

Fig. 6. Detection of WSBV by PCR with WSBV-specific primer sets 146 F2 and 146 R2 using DNA extracts from postlarval $P$. penicillatus immersed in filtrates from diseased $P$. monodon at 24,48 and $72 \mathrm{~h}$ p.i. Positive and negative control lanes as described in Fig. 4. Marker: pGEN DNA size marker. 
The reaction mixture used in PCR comprised: 100 pmol of each primer, $200 \mu \mathrm{M}$ of each dNTP, 2.5 units of Taq DNA Polymerase (Promega), $10 \mathrm{mM}$ Tris- $\mathrm{HCl}$ (pH 9.0 at $25^{\circ} \mathrm{C}$ ), $50 \mathrm{mM} \mathrm{KCl}, 1.5 \mathrm{mM} \mathrm{MgCl}{ }_{2}$ and $0.1 \%$ Triton X-100. The amplification was performed in an AG-9600 Thermal Station (Biotronics) for 1 cycle of $94^{\circ} \mathrm{C}$ for $3 \mathrm{~min}$, $60^{\circ} \mathrm{C}$ for $1 \mathrm{~min}, 72^{\circ} \mathrm{C}$ for $3 \mathrm{~min}$; and then 39 cycles of $94^{\circ} \mathrm{C}$ for $1 \mathrm{~min}, 60^{\circ} \mathrm{C}$ for $1 \mathrm{~min}$, $72^{\circ} \mathrm{C}$ for $3 \mathrm{~min}$; plus a final 5 min extension at $72^{\circ} \mathrm{C}$ after 40 cycles. A control reaction

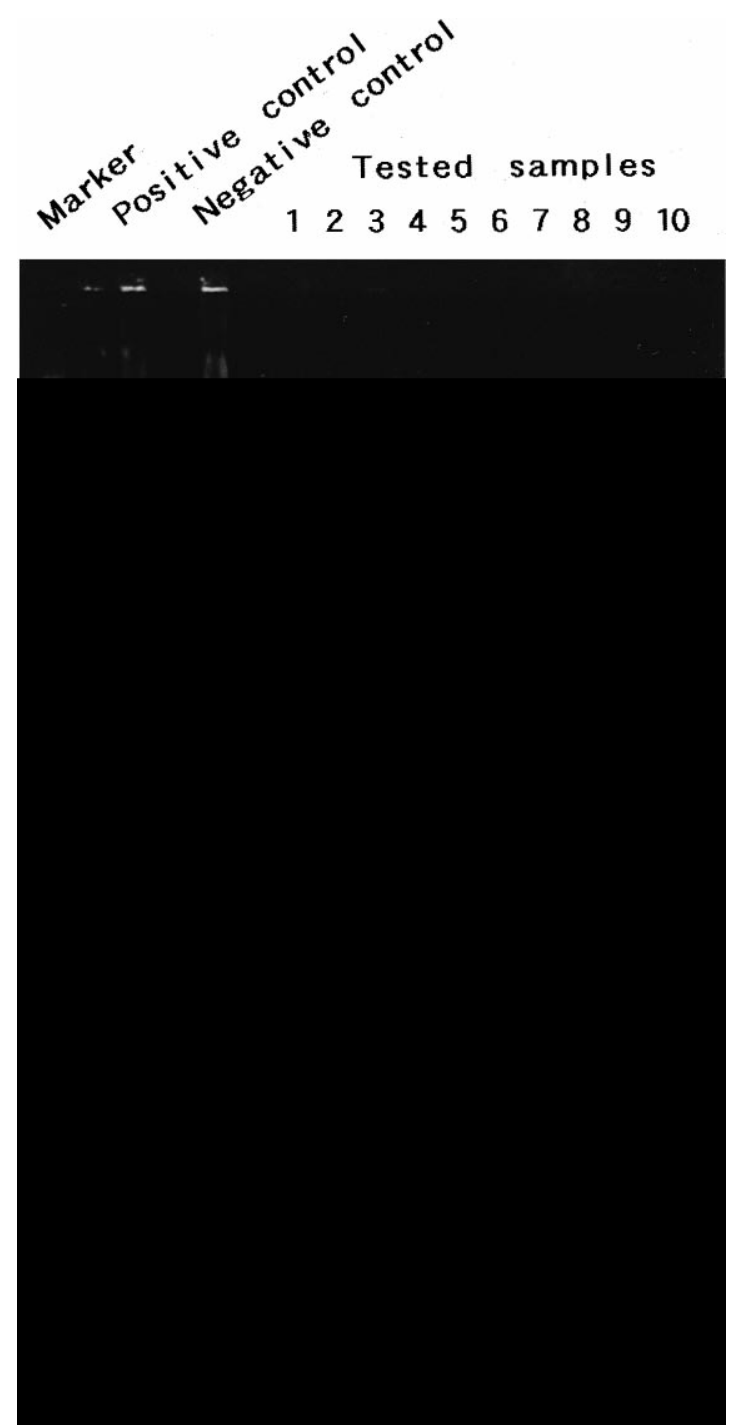

Fig. 7. Detection of WSBV by PCR with WSBV-specific primer sets 146 F2 and 146 R2 using DNA extracts from postlarval $P$. penicillatus immersed in filtrates from diseased $P$. japonicus at 24,48 and $72 \mathrm{~h}$ p.i. Positive and negative control lanes as described in Fig. 4. Marker: pGEN DNA size marker. 
was also performed using DNA extracted from healthy shrimp. The amplified products were analyzed by electrophoresis in $1 \%$ agarose gels containing ethidium bromide at a concentration of $0.5 \mathrm{mg} / \mathrm{ml}$, and visualized under ultraviolet transillumination.

\section{Results}

\subsection{Shrimp infectivity test via waterborne inoculation}

As Figs. 1 and 2 show, the inocula prepared from diseased $P$. monodon and $P$. japonicus were both highly pathogenic to the three tested shrimp species, cumulative mortalities reaching $100 \%$ within $4-6$ days. No shrimp died in the control groups. The typical white spots were observed on the carapace of the dead and moribund shrimp $5 \mathrm{~d}$ postinoculation. WSBV from either $P$. monodon or $P$. japonicus was found to be readily transmitted across different penaeid shrimp via waterborne contact.
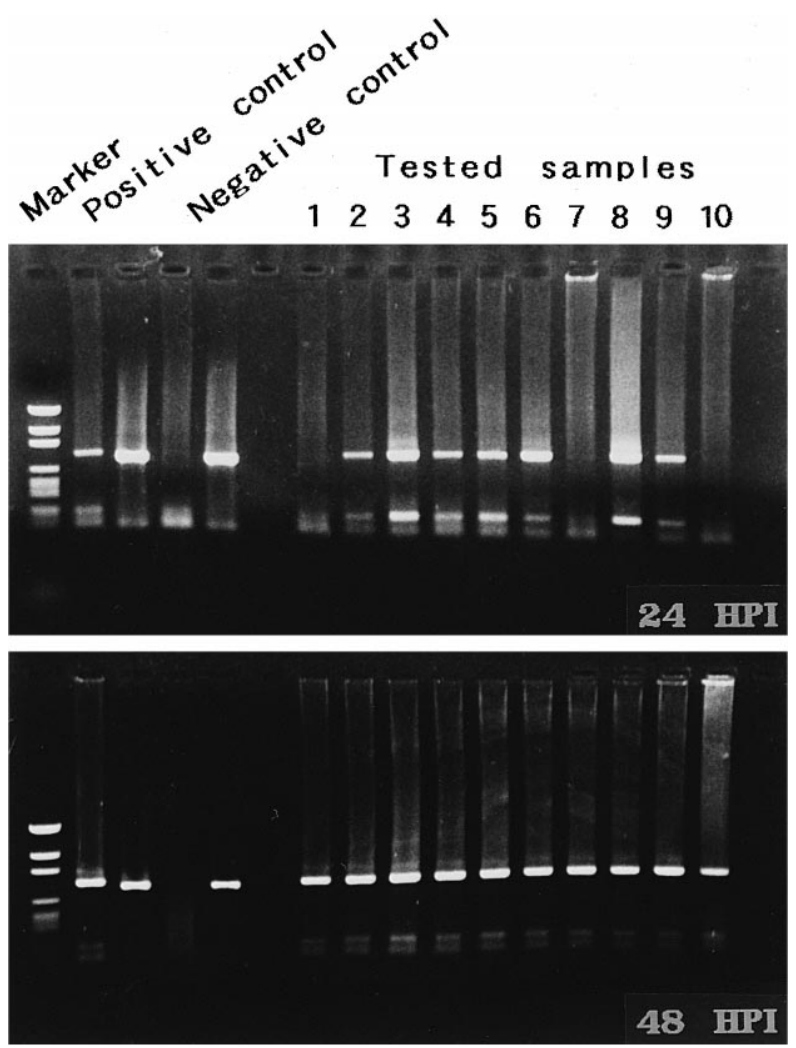

Fig. 8. Detection of WSBV by PCR with WSBV-specific primer sets 146 F2 and 146 R2 using DNA extracts from young adult $P$. monodon fed with diseased $P$. monodon at 24 and $48 \mathrm{~h}$ p.i. Positive and negative control lanes as described in Fig. 4. Marker: pGEN DNA size marker. 


\subsection{Shrimp infectivity test via oral ingestion}

White spots were first observed on the exoskeleton of a few experimentally infected P. monodon $48 \mathrm{~h}$ after being fed with muscle of diseased P. monodon or P. japonicus. All of the experimental shrimp died within $5 \mathrm{~d}$ and showed obvious white spots on the exoskeleton (Fig. 3). Informal pilot studies showed that market-sized shrimp (mean weight $10 \mathrm{~g}$ ) fed with diseased shrimp and reared in an intensive culture system began to show symptoms within 3-4 days and mortality reached $80-100 \%$ in 7 d. Bacilliform viral particles were observed in the pooled hemolymph of these artificially infected shrimp.

\subsection{Detection of WSBV in experimental shrimps by PCR}

With both the WSBV-specific primer set (146 F2 and $146 \mathrm{R} 2)$ and the shrimp DNA-specific primers (143 F and $145 \mathrm{R}$ ), a positive control containing DNA extracts from diseased shrimp and a negative control containing DNA from healthy shrimp were run for each PCR reaction. As shown in Fig. 4, a 941-bp WSBV amplification product
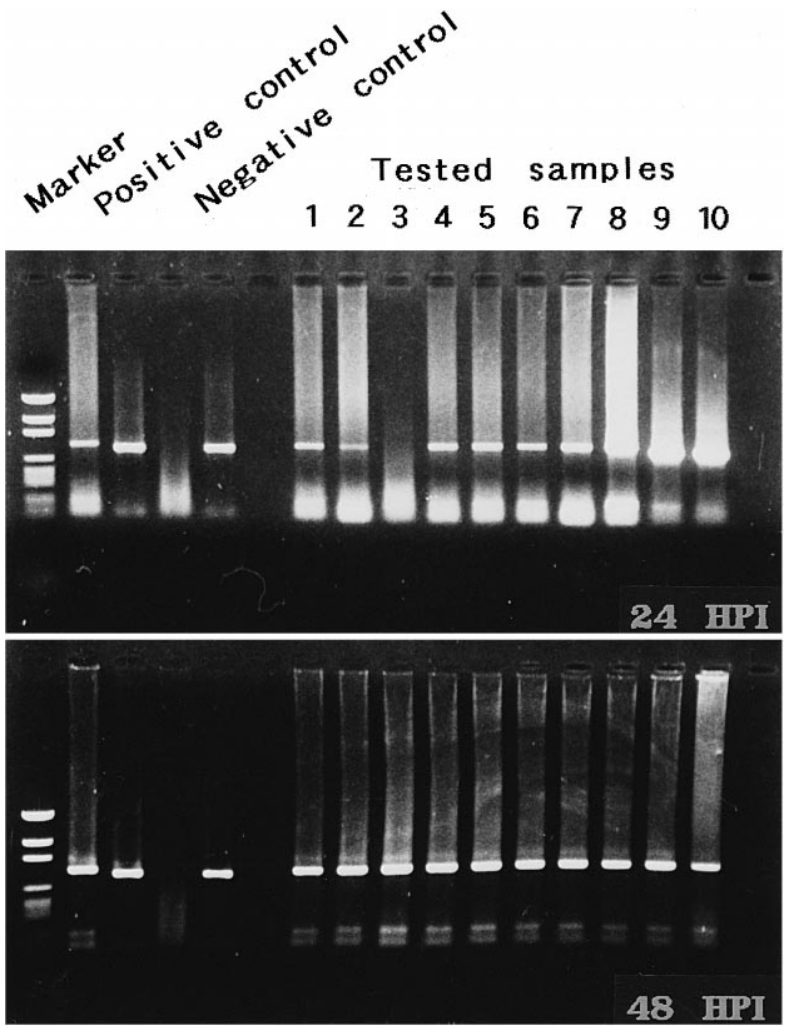

Fig. 9. Detection of WSBV by PCR with WSBV-specific primer sets 146 F2 and 146 R2 using DNA extracts from young adult $P$. monodon fed with diseased $P$. japonicus at 24 and $48 \mathrm{~h}$ p.i. Positive and negative control lanes as described in Fig. 4. Marker: pGEN DNA size marker. 
Table 1

Inoculation pathways and PCR-positive diagnosis

\begin{tabular}{lllll}
\hline \multirow{4}{*}{ Source of WSBV } & \multicolumn{3}{l}{ Shrimp species and size tested } \\
\cline { 2 - 5 } & $\begin{array}{l}\text { P. monodon } \\
\text { juveniles }(0.02 \mathrm{~g})\end{array}$ & $\begin{array}{l}\text { P. japonicus } \\
\text { juveniles }(0.08 \mathrm{~g})\end{array}$ & $\begin{array}{l}\text { P. penicillatus } \\
\text { postlarvae }(0.003 \mathrm{~g})\end{array}$ & $\begin{array}{l}\text { P. monodon } \\
\text { young adults }(1.5 \mathrm{~g})\end{array}$ \\
\hline Diseased P. monodon & waterborne & waterborne & waterborne & oral \\
& 24 h p.i. $(9 / 10)^{\mathrm{a}}$ & $\mathrm{N} / \mathrm{A}$ & $72 \mathrm{~h}$ p.i. $(7 / 7)$ & 24 h p.i. $(7 / 10)$ \\
Diseased $P$. japonicus & waterborne & waterborne & waterborne & oral \\
& $\mathrm{N} / \mathrm{A}$ & $\mathrm{N} / \mathrm{A}$ & $72 \mathrm{~h}$ p.i. $(6 / 6)$ & 24 hp.i. $(9 / 10)$ \\
\hline
\end{tabular}

${ }^{\mathrm{a}}$ Number positive/total number tested.

N/A: not available.

was found in the positive control (Lane 2) and an 848-bp shrimp DNA PCR product was present in the positive and negative control (Lanes 3 and 5). No WSBV amplification product was found in lane 4 which was the amplification result using WSBV specific primers and DNA extracted from healthy shrimps before being subjected to challenge tests. As can be seen in Figs. 5-9 (leftmost columns), similarly expected control results were obtained at each sampling time.

WSBV was first detected in P. monodon that had been immersed in filtrates from diseased P. monodon $6 \mathrm{~h}$ p.i. Although at $24 \mathrm{~h}$ p.i. the tested shrimp failed to show visible evidence of disease, at this time $90 \%$ positive results were found (Fig. 5). Only one of the 10 tested P. penicillatus immersed in filtrates from diseased P. monodon or $P$. japonicus showed WSBV-positive at $24 \mathrm{~h}$ p.i. All of the seven surviving $P$. penicillatus were, however, diagnosed as WSBV-positive by PCR at $72 \mathrm{~h}$ p.i. even though there was still no visible evidence of disease to be seen (Figs. 6 and 7). The presence of WSBV in $P$. monodon fed with either diseased $P$. monodon or diseased $P$. japonicus reached $80-90 \%$ at $24 \mathrm{~h}$ p.i. and $100 \%$ by 48 h p.i. (Figs. 8 and 9 ).

A summary of the major results obtained in all these infectivity tests is provided in Table 1.

\section{Discussion}

We had initially anticipated that an inoculum from one particular species might be significantly more pathogenic to specimens of that same species. However, no difference was found in the pathogenicity of WSBV from $P$. monodon and WSBV from $P$. japonicus when these two inocula were used to infect $P$. japonicus and $P$. penicillatus. Although not significant, some slight difference was nonetheless found in the mortality pattern of $P$. monodon immersed in filtrates prepared from diseased $P$. japonicus and P. monodon (Figs. 1 and 2). The reason for this seems to have been that although all replicates received identical treatment, the water quality in one of the experimental groups deteriorated more rapidly than in the others. This particular replicate contributed to the relatively rapid onset of $P$. monodon mortality shown in Fig. 1 . We feel this provides further (albeit slight) evidence of the impact that environmental management (in this case water quality) can have on WSBV infected shrimp mortality. Other aspects of environmental stress management are considered below. 
Our pilot studies have shown that the larger, market-sized shrimp ( $P$. monodon average $10 \mathrm{~g}$ ) are relatively nonsusceptible to waterborne inoculation, and even when fed WSBV-containing tissue, they typically do not succumb to the disease. Nonetheless they are infected, and under the stressful conditions of a high-density culture system, this WSBV infection can prove fatal. This phenomenon has also been documented in cases involving MBV and HHNBV as well as WSBV, where increased environmental stress (crowding, shipping, temperature and catching stress) is positively correlated with increased mortality (Couch et al., 1975; Chen et al., 1989; Cai et al., 1995; Chou et al., 1995).

Although the shrimp viral diseases listed in the introduction are a fairly recent phenomenon and have been confirmed in Asia, a variety of infectious viral diseases have been reported worldwide in cultured penaeid shrimps over the last 20 years. Monodon baculovirus (MBV), baculoviral midgut necrosis virus (BMNV), Baculovirus penaei (BP) and infectious hypodermal and hematopoietic necrosis virus (IHHNV) are all well documented shrimp viruses (Couch, 1974; Lightner and Redman, 1981; Lightner et al., 1983a,b, 1987; Sano et al., 1981). Morphological, histological, epizoological, geographical and diagnostic studies of these shrimp viruses provided valuable information and has led to the control of these diseases (Leblanc and Overstreet, 1991; Lewis et al., 1992; Lightner, 1988; Lu et al., 1993; Momoyama, 1989). Such detailed information on the causative viral agents of the recent outbreaks in Asia, however, are only just beginning to emerge. Although these newly reported rod-shaped viruses are different in morphology, histopathology and geographic distribution, epidemiological circumstances lead us to suspect that at least some of these viral agents might in fact be closely related. Further comparative studies on the genomic structure of these viruses are needed to clarify their relatedness. This in turn will contribute to a better understanding of these virus etiologies, diagnosis, transmission, host and geographic range, and it is only by being armed with this knowledge that we can hope to develop effective control measures against these diseases and ensure the continued growth of the shrimp culture industry in Asia.

\section{Conclusion}

The results of the present study suggest that WSBV can be transmitted orally as well as via water across shrimp species. Given the cannibalistic nature of shrimp, transmission of WSBV via oral ingestion is an important route for the dissemination of the virus through shrimp populations. Due to its rapid spreading, virulence and broad host range, we anticipate WSBV will increasingly infect a variety of species of cultured shrimp worldwide and cause serious damage to shrimp production. If the disease is to be successfully combated, development of effective control measures is urgently needed. Lo et al. (1996) developed WSBV-specific primer sets, and with these primers, we detected WSBV from experimentally infected but healthy-looking shrimp in this study. These techniques will be useful both for the screening of carriers in shrimp larvae, parental spawners and invertebrate populations which share the same habitat as well as in helping to ascertain the transmission and infection cycle of WSBV. 


\section{Acknowledgements}

The authors express their appreciation to Mr. W.B. Yu and Mr. W.T Hong, I-Lan Livestock Disease Control Center, for sampling assistance.

\section{References}

Cai, S., Huang, J., Wang, C., Song, X., Sun, X., Yu, J., Zhang, Y., Yang, C., 1995. Epidemiological studies on the explosive epidemic disease of prawn in 1993-1994. J. Fish China 19, 112-1171, in Chinese.

Chen, S.N., Chang, P.S., Kou, G.H., 1989. Observation on pathogenicity and epizootiology of Penaeus monodon Baculovirus (MBV) in cultured shrimp in Taiwan. Fish Pathol. 24, 189-195.

Chou, H.Y., Huang, C.Y., Wang, C.H., Chiang, H.C., Lo, C.F., 1995. Pathogenicity of a baculovirus infection causing white spot syndrome in cultured penaeid shrimp in Taiwan. Dis. Aquat. Org. 23, 165-173.

Couch, J.A., 1974. An enzootic nuclear polyhedrosis virus of pink shrimp: Ultrastructure, prevalence, and enhancement. J. Invertebr. Pathol. 24, 311-331.

Couch, J.A., Summers, M.D., Cowtney, L., 1975. Environmental significance of baculovirus infections in estuarine and marine shrimp. Ann. New York Acad. Sci. 266, 528-536.

Erlich, H.H., Gelfand, D.H., Saiki, R.K., 1988. Specific DNA amplification. Nature 331, 461-462.

Inouye, K., Miwa, S., Oseko, N., Nakano, H., Kimura, T., 1994. Mass mortalities of cultured kuruma shrimp, Penaeus japonicus, in Japan in 1993: Electron microscopic evidence of the causative virus. Fish Pathol. 29, $149-158$, in Japanese.

Inouye, K., Yamano, K., Ikeda, N., Kimura, T., Nakano, H., Momoyama, K., Kobayashi, J., Miyajima, S., 1996. The penaeid rod-shaped DNA virus (PRDV), which causes penaeid acute viremia (PAV). Fish Pathol. 31, 39-45.

Leblanc, B.D., Overstreet, R.M., 1991. Efficacy of calcium hypochlorite as a disinfectant against the shrimp virus Baculovirus penaei. J. Aquat. Animal Health 3, 141-145.

Lewis, D.H., Charanzn, W.M., Omran, M.T., 1992. Baculovirus-impregnated filter paper method for assessing disinfection protocols in shrimp mariculture facilities. J. Aquat. Animal Health 4, 69-72.

Lightner, D.V., 1988. MBV virus disease of penaeid shrimp. In: Sindermann, C.J., Lightner, D.V. (Eds.), Disease Diagnosis and Control in North American Marine Aquaculture. Elsevier, Amsterdam, pp. 22-25.

Lightner, D.V., Redman, R.M., 1981. A baculovirus-caused disease of the Penaeid shrimp, Penaeus monodon. J. Invertebr. Pathol. 38, 299-302.

Lightner, D.V., Redman, R.M., Bell, T.A., 1983a. Observations on the geographic distribution, pathogenesis and morphology of the baculovirus from Penaeus monodon Fabricius. Aquaculture 32, 209-233.

Lightner, D.V., Redman, R.M., Bell, T.A., 1983b. Infectious hypodermal and hematopoietic necrosis (IHHNV), a newly recognized virus disease of penaeid shrimp. J. Invertebr. Pathol. 42, 62-70.

Lightner, D.V., Hedrick, R.P., Postlarvaer, J.L., Chen, S.-N., Liao, I.-C., Kou, G.-H., 1987. A survey of cultured penaeid shrimp in Taiwan for viral and other important diseases. Fish Pathol. 22, 127-140.

Lo, C.F., Leu, J.H., Ho, C.H., Chen, C.H., Peng, S.E., Chen, Y.T., Chou, C.M., Yeh, P.Y., Huang, C.J., Chou, H.Y., Wang, C.H., Kou, G.H., 1996. Detection of baculovirus associated with white-spot syndrome (WSBV) in penaeid shrimps using polymerase chain reaction. Dis. Aquat. Org. 25, 133-141.

Lu, C.C., Tang, K.F.J., Kou, G.H., Chen, S.N., 1993. Development of a Penaeus monodon-type baculovirus (MBV) DNA probe by polymerase chain reaction and sequence analysis. J. Fish Dis. 16, 551-559.

Momoyama, K., 1989. Inactivation of baculoviral midgut gland necrosis (BMNV) virus by ultraviolet irradiation, sunlight exposure, heating and drying. Fish Pathol. 24, 115-118, in Japanese.

Momoyama, K., Hiraoka, M., Nakano, H., Koube, H., Inouye, K., Oseka, N., 1994. Mass mortalities of cultured kuruma shrimp, Penaeus japonicus, in Japan in 1993: Histopathological study. Fish Pathol. 29, $141-148$, in Japanese.

Nakano, H., Koube, H., Umezawa, S., Momoyama, K., Hiraoka, M., Inouye, K., Oseko, N., 1994. Mass mortalities of cultured kuruma shrimp, Penaeus japonicus, in Japan in 1993: Epizootiological survey and infection trials. Fish Pathol. 29, 135-139, in Japanese. 
Oste, C., 1988. Polymerase chain reaction. Biotechniques 6, 162-167.

Sano, T., Nishimura, T., Oguma, K., Momoyama, K., Takeno, N., 1981. Baculovirus infection of cultured kuruma shrimp Penaeus japonicus in Japan. Fish Pathol. 15, 185-191.

Takahashi, Y., Itami, T., Kondo, M., Maeda, M., Fujii, R., Tomonaga, S., Supamattaya, K., Boonyaratpalin, S., 1994. Electron microscopic evidence of bacilliform virus infection in kuruma shrimp (Penaeus japonicus). Fish Pathol. 29, 121-125.

Wang, C.H., Lo, C.F., Leu, J.H., Chou, C.M., Yeh, P.Y., Chou, H.Y., Tung, M.C., Chang, C.F., Su, M.S., Kou, G.H., 1995. Purification and genomic analysis of baculovirus associated with white-spot syndrome (WSBV) of Penaeus monodon. Dis. Aquat. Org. 23, 239-242.

Wongteerasupaya, C., Vickers, J.E., Sriurairatana, S., Nash, G.L., Alarajamorn, A., Boonsaeng, V., Panyim, S., Tassanakajon, A., Withyachumnarnkul, B., Flegel, T.W., 1995. A nonoccluded, systemic baculovirus that occurs in cells of ectodermal and mesodermal origin and causes high mortality in the black tiger prawn Penaeus monodon. Dis. Aquat. Org. 21, 69-77. 